\title{
POEMAS DESDE ISLA ROBINSON CRUSOE
}

POEMS FROM ROBINSON CRUSOE'S ISLAND 


\section{ALGUNA VEZ SE AMA}

Alguna vez se ama

La vida cotidiana

Los botecitos blancos

La forma de los árboles

Y las mareas turbias de donde los peces huyen

El cielo se llena de aleteos

$\mathrm{Y}$ graznidos que quiebran la noche

Días de invierno que nadie mira la luz huye de sí misma

Fogatas son parte de la palidez del horizonte

$Y$ ojos que no terminan de devorar el fuego

$Y$ las voces que no recordamos de los amigos que ya se fueron

Fogatas nocturnas.

No importa quién eres alguna vez se ama.

\section{Nuevo Sueño}

Renace en mí un nuevo sueño

Y existo después del temporal

El pasto verde renace después de ser pisoteado

Los cipreses no recuerdan el nido del pájaro

Mientras escuchamos los pasos de nuestros amigos que se van

Y el eco del adiós se plasma de lágrimas en el muelle.

Y atragantados de adioses y las últimas miradas

Sobrevivimos después de cerrar los ojos

Y ya son sólo recuerdos como el lento desaparecer del barco en la distancia.

\section{TARDES EN PENUMBRAS}

La tarde se ha tornado rosa

La penumbra muestra siluetas de cerros, mar quieto y silencio

Gente en bicicleta pasea pensamientos en sueños

Los arboles se mecen suavemente con la brisa del paso

Inspirando al zorzal a cantar su última canción.

Por la noche bajará la fardela tímidamente graznando lastimera

Revoloteando en rondas de amor y sin más horizontes.

\section{ERosión}

Bajo un manto de verde espesor,

Bajo un manto

Contraste agreste

Tierra inhóspita

Donde el agua se desliza

Sin ningún impedimento.

El viento la ha azotado por eras y tiempos

Marchitando sus cerros,

Aniquila quebradas terminando con la vida amada.

Mas la mano del hombre ha ayudado a destruir la belleza

Quitando bosques de lumas y helechos.

\section{Luna Dócil}

Noche corre como el viento
No dejes que la luna se escape

Detenla por un momento,

Que no se quite los trajes. Yo no la quiero así

Para vivir no quiero sólo a la isla.

Luna vuelve dócil a tu destino.

Qué alegría verte de nuevo

Danzando en un mundo vacío

Que los astros te veneren.

Permite que mi alma sea tan clara y libre

Como el alma tuya.

Déjame soñar alto, buscar los atajos difíciles,

Donde carrozas tiradas por blancos caballos me lleven

Camino a la exaltación.

Tratando de reparar el daño,

Construye dique de contención para ver si algún día nace el verdor

\section{FANTASMA}

Fantasma apareció un día como una fantasma ilusión. Fantasma camina por senderos

Recorriendo de prisa valles y quebradas

Duerme entre helechos y se empapa con la lluvia clara.

Fantasma esparce perfumes

Para conquistar al picaflor

Penetra por los bosques

Besa al yunque por las mañanas

Inunda la isla

Y se esconde en las cuevas para oler el musgo

-Ondas de eco aun repercuten-

Sale y persigue a los pescadores

Recuerda lo que fueron sus huesos

Lo que fueron sus venas.

Ya no existe. Brama y nadie le escucha

El brillo de la brisa le lleva a ocultarse

En una isla dejando una fantasma ilusión.

\section{Botecitos Dormidos}

Campos de flores adornan paisajes

La tarde esta callad

Ni voces ni ladridos de perros

Los árboles apiñados

Muestran matices de verdores

Tan quietos están que parecen dormidos

Botecitos blancos de calma

Los mares oceánicos les mecen

Como si la noche se los tragase.

Amanecen ordenados,

Como si durmiesen reposando en la calidez

Del pescador

Que en cada amanece

Atraviesa la isla

Buscando mares de ilusión. 


\section{Al Oeste te Acaricia la Brisa}

Arrímate al oeste y ven a refugiarte en el silencio

Que acaricie la brisa tu pelo junto a helechos y chontas

Disfruta de profundas vegetaciones ancladas,

Y el silencio te sorprenderá con cantos de pinguiritas

Sentirás en tu alma la paz infinita

Quebradas y picachos serán panoramas de tus recuerdos.

Dejarás que la idiosincrasia de mi pueblo te cobije en un abrazo eterno.

\section{Tempestad I}

Silba el viento,

Y el mar embravecido,

Como queriendo recogerse.

Recuerdos del último temporal trágico

Hay en la memoria taciturna,

Sólo dejó el silencio que nadie entiende.

El pan de una mesa sacó

Arrancó un amor

Al niño adolescente sin padre

Muchas rosas lleva su pecho

Dejando un rastro de lágrimas.

Los dos compadres

Al viento desafiaban

Vértigos y desconsuelos ni golondrinas en vuelo

Tan jóvenes

Que subieron al paraíso

Siempre en el viento les recordaremos.

\section{Tempestad II}

La isla cubierta por llovizna

Se confunde con el mar gris.

Vientos que barren las aguas

Vienen y van apresurados.

Vienen y van apresurados.

Un baro se distingue

Entre lluvias que pasan

En el viento del norte.

Los pescadores pasan, avanzan de pris

En vez de langostas valo

Ellos saben defenderse

De hoyos como barrancos que les llevan a la mar.

En casa cierran puertas y ventanas,

El pan en la mesa oraciones y plegarias

El murmullo se lo lleva el viento

Ya no podrán dormirse

Quizás al alba no volverán a verles.

\section{Silencio en el Silencio}

Qué silencio

Qué temor,
Qué sonrisa,

¡Qué silencio!

Un murmullo, unos pasos

Rutina que no abrazo porque mata el día.

Deja paso a la noche,

Paso a otro día.

Sentir en cada movimiento que la vida es mía.

Fui elegida para nacer en esta tierra.

No merezco olvido

Ni tampoco desamor,

Sólo quiero amar al picaflor

También cansado del silencio

¿Cómo roba la tarde!

¿Cómo moja la lluvia las hojas de la col!

Como las distancias al barco en la mar.

\section{Gotitas DE LLUVIA EN MIS OJOS}

Quédate y abre los brazos.

Déjate llevar por mi amor,

Y en cada madrugada encontraremos al sol.

Nuestros cuerpos estarán juntos.

Puedo amarte más y vivir en el fuego de tus besos.

Quédate y mírame en lo profundo del mar.

Reacuérdame en el encanto de esta tierra. 